Манаєнко I. М. канд. економ. наук ORCID ID: 0000-0002-3246-3603 Національний технічний університет Украйни «Київський політехнічний інститут імені Ігоря Сікорського»

\title{
РОЗВИТОК МІЖНАРОДНОГО ФАКТОРИНГУ В КОНТЕКСТІ ПОСТІНДУСТРІАЛІЗАЦЇ̈ СВІТОВОЇ ЕКОНОМІКИ
}

\author{
РАЗВИТИЕ МЕЖДУНАРОДНОГО ФАКТОРИНГА В КОНТЕКСТЕ \\ ПОСТИНДУСТРИАЛИЗАЦИИ МИРОВОЙ ЭКОНОМИКИ
}

\section{INTERNATIONAL FACTORING DEVELOPMENT IN THE WORLD ECONOMY POSTINDUSTRIALIZATION}

Стаття присвячена дослідженню розвитку факторингових операцій в світовій економіці. Зазначено основні історичні етапи формування факторингу, країни його зародження та розвитку. Наведено основні міжнародні організації у сфері факторингу, їх роль у регулюванні фінансової послуги в умовах постіндустріалізації. Представлено географічний розподіл факторингових операцій за регіонами світу, визначено тендениії їі видозміни. Обгрунтовано відмінність факторингу від банківського кредитування. Визначено основні переваги даних операцій. Сформовано перелік факторів зовнішнього середовища, щуо впливають на розвиток факторингу в краӥні. Наведено перелік основних комісійно-посередницьких послуг, щуо супроводжують факторингове обслуговування. Здійснено обтрунтування основних принципів. Досліджено ринок факторингу в Украӥні, приведено особливості надання факторингових послуг вітчизняними банківськими установами. Представлено тендениії розвитку факторингу в країнах-сусідах України, зроблено порівняльну характеристику.

Ключові слова: розвиток, ризик, постіндустріалізація, світова економіка, факторинг, фінансовий ринок.

Статья посвящена исследованию развития факторинговых операџий в мировой экономике. Указаны основные исторические этапь формирования факторинга, страны его зарождения и развития. Приведень основные международные организации в сфрере факторинга, их роль в регулировании финансовой услуги в условиях пост индустриализации. Представлены географическое распределение факторинговых операций по регионам мира, определены тенденции ее видоизменения. Обоснованно отличие факторинга от банковского кредитования. Определены основные преимущества данных операчий. Сформирован перечень факторов внешней среды, влияющих на развитие факторинга в стране. Приведен перечень основных комиссионно-посреднических услуг, сопутствующих факторинговое обслуживание. Осуществлено обоснование основных принцииов. Исследован рынок факторинга в Украине, приведень особенности предоставления факторинговых услуг банковским учреждениям. Представлены тенденщии развития факторинга в странах-соседях Украины, сделано сравнительную характеристику. 
Ключевые слова: развитие, риск, постиндустриализация, мировая экономика, факторинг, финансовый рынок.

The article investigates the development of factoring in the global economy. Outlines the historical stages of factoring country of its origin and development. The basic international organizations in the field of factoring and their role in the regulation of financial services in terms post industrialization. Presented by the geographic distribution of factoring operations by region of the world, its trends identified modifications. Factoring proved the difference on bank lending. The main advantages of these operations. Formed a list of environmental factors that influence the development of factoring in the country. The list of basic services intermediary a commission accompanying the factoring service. Done justification of basic principles. Investigated the factoring market in Ukraine, given the peculiarities of factoring services domestic banks. Presented trends of factoring in neighboring countries Ukraine, made comparisons.

Keywords: development, risk post industrialization, the global economy, factoring, financial market.

Вступ. Турбулентний розвиток світового господарства останніх десятиліть породжує активізацію імплементації низки фінансових послуг, що $\epsilon$ підтвердженням всеохоплюючої постіндустріалізації. Активність використання тієї чи іншої фінансової послуги є наслідком комплексного розвитку суб'єктів господарювання країни, які потребують нових унікальних інструментів фінансового забезпечення. Однією із таких послуг $\epsilon$ факторингове обслуговування. Важливість даної послуги підтверджується іiі активних використанням у країнах Свропи, де оборот факторингу становить $6 \%$ від ВВП.

За порушеною тематикою існує значна кількість наукових публікацій. Зокрема вагомий вклад у визначення теоретичних засад факторингу здійснили Гриценко В. В. [9], Карп'як Я. С. [1], Сисоєв О. В. [8]. Визначенню особливостей розвитку факторингу в Україні присвячені праці Момот Л. В. [10], Поліщук О. В. [2], Казакова М. О. [7] та інші. Проте зміна векторів та акцентів розвитку міжнародного факторингу в світовій економіці потребує проведення подальших наукових досліджень, що мають грунтуватись як на теоретичних засадах факторингу, так і на аналітичній інформації щодо тенденцій розвитку даної сфери.

Постановка завдання. Метою даного дослідження $\epsilon$ визначення тенденцій розвитку факторингу в умовах постіндустріалізації світової економіки на основі детермінації основних факторів макроекономічного характеру, котрі впливають на реалізацію факторингових операцій.

Методологія. Теоретичною основою дослідження виступають наукові доробки зарубіжних і вітчизняних учених з теорії та практики факторингових операцій. Для досягнення визначеної мети й поставлених завдань використано систему загальнонаукових та спеціальних методів, а саме: методи системнофункціонального підходів до теоретичного поглиблення теми дослідження; 
методи систематизації, групування та узагальнення, формалізації з метою формування переліку переваг факторингу та його принципів, виявлення його відмінностей від банківського кредитування; методи індукції та дедукції, наукової абстракції, методи структурно-логічного та семантичного аналізу для виявлення основних тенденцій розвитку факторингу в сучасному господарському комплексі світу тощо.

Результати дослідження. Започаткував операції факторингу Будинок факторів (House of Factors), котрий створений у Великій Британії ще у XVII столітті. Перед фактором, який володів знаннями щодо тенденцій розвитку товарного ринку, знав закони та торгові звичаї країни, висувалося завдання пошуку надійних покупців, зберігання та збуту товару, а також наступної інкасації торгової виручки. На відміну від Європи, активний розвиток факторингових операцій зароджується у Північній Америці лише у другій половині XIX ст. Сучасні види факторингу вперше класифікував в 1947 p. американський банк «The First National Bank of Boston». Однак, офіційно факторингові послуги в США було визнано в 1963 р., коли урядова організація - Контролер грошового обігу - прийняла рішення про законність надання банками такої послуги. У Великій Британії першу факторингову компанію було відкрито в 1960 р., у Німеччині - в 1963 р. У Франції процедуру факторингу, яка відповідає англо-американським методам і 3 елементом рефінансування комерційних зобов'язань на короткий термін (менше 180 днів), запроваджено в 1965 р. [1, с. 72] Наприкінці 1950-х - на початку 1960-х років було створено три міжнародні факторингові групи, без яких неможливе існування сучасного міжнародного факторингу: Heller International Group, International Factors Group S.C., Factors Chain International. Лише одна із них - International Factors Group S.C. - об'єднує 58 факторингових компаній у 35 країнах світу, а іï частка на світовому ринку факторингових послуг становить приблизно 28 \%. На сьогодні, головне завдання факторингових компаній більшості країн Європи, які тісно пов'язані 3 великими банками, полягає у фінансуванні дебіторської заборгованості на основі використання «регресного» факторингу [2].

У зв'язку з розвитком факторингу та з'ясування його загальновизнаної сутності у 1988 р. було прийнято Конвенцію про міжнародний факторинг, згідно якої фінансова операція вважається міжнародним факторингом лише у тому разі, якщо виконується принаймні дві з чотирьох умов [3]: наявність кредитування у формі попередньої сплати боргових вимог; ведення бухгалтерського обліку постачальника, передусім обліку збуту; інкасування його заборгованості; страхування постачальника від кредитного ризику.

Розвиток постіндустріалізації світової економіки зумовлює зародження на розвиток міжнародних організацій. Відтак у сфері факторингу відома така міжнародна асоціація як Міжнародна факторингова група (IFG), що заснована 
в 1963 p. і наразі об'єднує близько 140 факторів 356 країн. Не менш ваговою є Міжнародна факторингова мережа (FCI), заснована в 1968 р., на сьогодні об'єднує 244 фактори 365 країн. Суттєвою відмінністю у діяльності даних асоціацій $\epsilon$ те, що Міжнародна факторингова група допомагає у здійсненні транскордонних факторингових операцій шляхом встановлення кореспондентських відносин між факторами, які є членами групи, тобто має місце двофакторний факторинг, в той час як діяльність Міжнародної факторингової мережі спрямована на сприяння розвитку факторингу та супутніх йому послуг в глобальному масштабі, а також, що головне, розробку стандартів здійснення факторингових операцій [4, с. 165]. В сучасних умовах у зв'язку з процесами постіндустріалізації набуває актуальності налагодження співпраці між основними факторинговими асоціаціями 3 метою створення єдиної європейської факторингової мережі. Ця ідея виникла саме в умовах глобальної фінансової нестабільності - в 2008 р., а в 2009 р. вже було створено Свропейський форум для факторингу та комерційних фінансів, який $\epsilon$ платформою для об'єднання зусиль провідних національних та міжнародних асоціацій в зазначених сферах. У травні 2009 р. членство у Форумі отримали вісім факторингових асоціацій, зокрема дві міжнародні асоціації (IFG, FCI) та шість національних асоціацій з таких країн, як Великобританія, Франція, Німеччина, Італія, Польща, Іспанія [5, с. 5]. Зусилля Форуму спрямовуються передусім на створення уніфікованих стандартів здійснення факторингових операцій в рамках Свропейського Союзу, а також узагальнення та аналіз статистики в сфері факторингу та комерційних фінансів не тільки в Європі, а й у світі.

Наразі факторинг продовжує переважати у фінансуванні торгових угод, на частку яких припадає до $80 \%$ в загальному обсязі світового факторингу. Частка європейських країн перевищує $70 \%$ від загального обороту факторингу, а серед європейських країн $20 \%$ зберігає за собою Великобританія, де найбільш активно факторинг як і раніше застосовується саме в текстильній промисловості (20\% в галузевій структурі факторингу). Як інструмент торгового фінансування факторинг займає в показниках макроекономічної статистики. В середньому по Європі оборот факторингу становить 6\% від ВВП. У ряді країн Середземноморського басейну цей показник досягає 15-20\%. Географічний розподіл факторингових операцій представлено на рис. 1. 


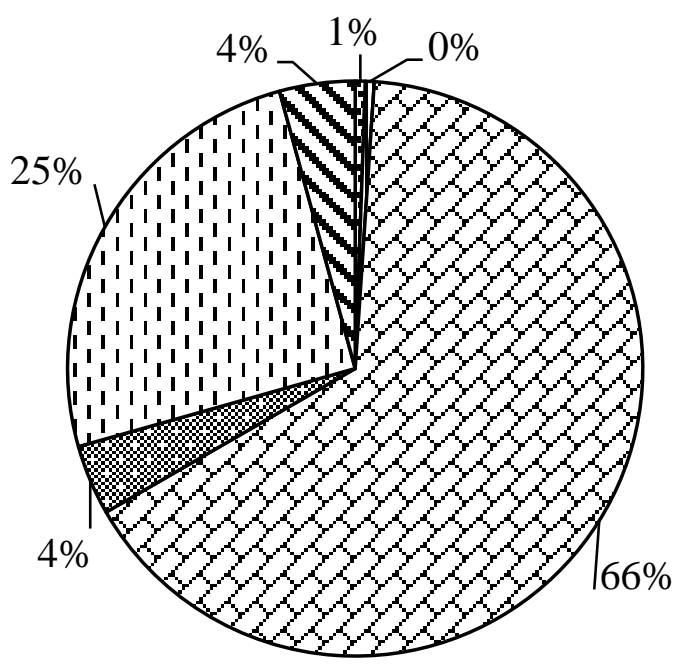

๑Африка

四 Близький Схід

凶Європа

П Південна

Америка

ФПівденно-

Східна Азія

ФПівнічна

Америка

Рис. 1. Географія факторингу в 2015 р., \%

Побудовано автором за даними FCI [6]

Традиційно лідером у здійсненні факторингових операцій залишаються факторингові компанії Свропи, на які припадає близько 70\% світового факторингу. Цьому сприяли зародження даної послуги саме у Європі (i Європейський форум факторингу також цьому аргумент), а також те, що даний регіон тривалий час утримує світове лідерство за розвитком фінансового ринку. Друге місце у здійсненні факторингу належить країнам Південно-Східної Азії - близько 25 \%, але до світової фінансової кризи другу позицію займала Північна Америка, яка наразі становить лише $4 \%$. Зазначений перерозподіл буде тривати й надалі, особливо під впливом розвитку постіндустріалізації в азійському регіоні.

Відповідно до видів факторингових операцій, обсяги міжнародного факторингу значно менші, ніж внутрішнього. Це зумовлено тим, що практика використання міжнародного факторингу є досить незначною але він активно розвивається. Наприклад, 32004 по 2008 рр. - обсяги міжнародного факторингу зросли у 2,5 рази, а внутрішнього - лише у 1,5 рази. Аналогічно, у період 2010 - 2015 рр. обсяги міжнародного факторингу збільшились в 2,2 рази, водночас внутрішнього - лише в 1,3 (рис. 2). 


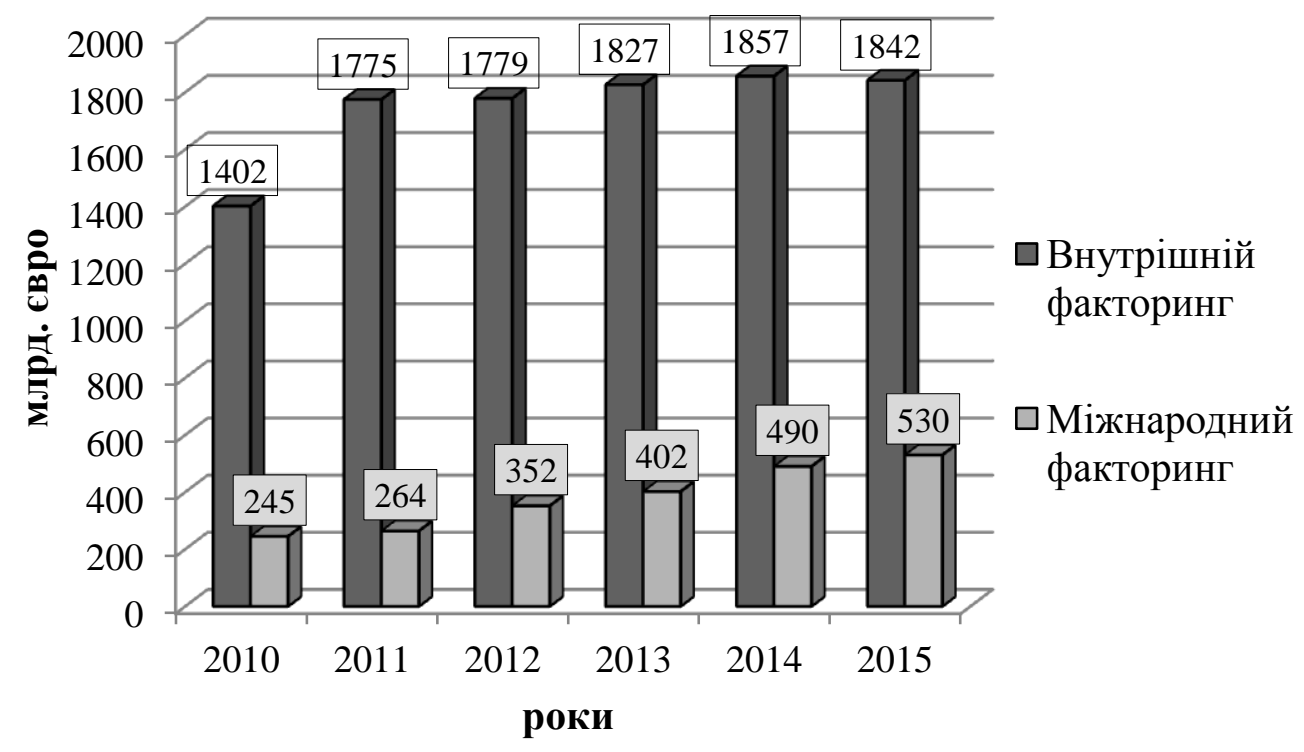

Рис. 2. Тенденції розвитку факторингу в світі, млрд. євро Побудовано автором за даними FCI [6]

В даний час факторинг широко використовується в комерційній практиці як спосіб додаткового фінансування i забезпечення. Він активно застосовується у фармацевтичній галузі, при продажу канцелярських товарів, постачання продуктів харчування і товарів народного споживання провідним роздрібним мережам. Серед всесвітньо відомих компаній, для яких факторингове обслуговування служило підтримкою на всіх етапах свого розвитку, Acer (комп'ютерна техніка, Тайвань); Parmalat (продукти харчування, Італія); Lewis Global Toys (товари для дітей, США).

Тривалий час існувала невизначеність у відмінностях факторингу від банківського кредитування. Однак між наданням факторингових послуг i банківським кредитуванням є суттєві відмінності, основні 3 них полягають у наступному [2]: надається на строк фактичної відстрочки платежу, а кредит на визначений термін; виплачується в день поставки товару, а кредит - в обумовлений кредитним договором день; не потребує забезпечення, тоді як кредит, надається під заставу; погашається коштами, що виплачуються дебіторами клієнту, а кредит повертається банку позичальником; погашається в день фактичної оплати дебітором отриманого товару; виплачується автоматично при пред'явленні накладної та рахунку-фактури, а для отримання кредиту потрібно оформити низку документів.

За здійснення факторингового фінансування клієнт проводить банку наступну оплату: відсоткову ставку за фінансування, яка залежить від терміну відстрочки платежу за контрактом, укладеного між клієнтом та його боржником; комісію за фінансування, яка сплачується одноразово в день видачі фінансування як відсоток від суми наданого фінансування. 
Факторингова компанія відразу виплачує клієнту від $70 \%$ до $90 \%$ потрібних йому грошей у вигляді кредиту, а залишок (без проценту за кредит та комісію за факторингові послуги) перераховують після стягнення всього боргу.

Варто зазначити, що С. Ю. Курбатов перший поставив питання про принципи факторингу. Він вважає, що їх значення полягає в тому, що вони відображають сутність факторингового обслуговування, його характерні риси, слугують основою самого здійснення факторингу. Порушення цих принципів може стати основою для розірвання договору між суб'єктами факторингу. До принципів факторингу С. Ю. Курбатов відносить такі принципи: конкретність, цілеспрямованість, правомірність, оперативність, невідворотність відповідальності [8].

Унікальність такого кредитного інструменту, як факторинг, полягає у таких його перевагах [7]:

1. Факторинг - це інструмент, що сприяє розширенню частки компанії на ринку. Після отримання необхідних оборотних коштів 3'являється можливість збільшити обсяги продажів.

2. Отримання додаткового прибутку. Поповнення оборотних коштів i збільшення обсягу продажів відповідно буде сприяти збільшенню прибутку.

3. Доступність і прозорість процедури. При факторингу, на відміну від банківського кредитування, фінансування не вимагає заставного забезпечення, а також відкриття додаткового поточного рахунку та переведення оборотів.

4. Нові конкурентні переваги. Компанія отримує можливість надавати клієнтам конкурентні відстрочки платежу, підтримуючи при цьому необхідний асортимент товарів на складі за рахунок додаткових оборотних коштів.

5. Подолання проблеми касових розривів. Індивідуальний графік проведення операцій з фінансування дозволить отримати гроші в будь-який момент після відвантаження товару. Фінансування, що надається, поступово збільшується в міру зростання продажів, при цьому в компанії залишається можливість використання кредитних лімітів у банку.

6. Поліпшення фінансових показників. Факторинг без регресу дає можливість істотно поліпшити фінансові показники за рахунок скорочення дебіторської заборгованості.

Проте перед використанням факторингових послуг слід пам'ятати про те, що [7]: чітких рекомендацій щодо вираження факторингових операцій у бухгалтерському обліку немає; існують протиріччя в нормативних актах щодо податкових зборів 3 факторингових операцій в Україні; фінансування на кожного дебітора на основі проведеного фінансового аналізу діяльності клієнта та дебітора обмежується. 
Незважаючи на низку переваг такого інструментарію як факторинг, доцільно наголосити, що ваговий вплив відіграють фактори макроекономічного характеру, до яких пропонується відносити:

1) трудоресурсні: частка населення 3 вищою освітою, яка може працювати в сфері розробки та імплементації факторингових операцій на вітчизняному ринку, а також фахівців-консультантів, що мають досвід роботи у зарубіжних факторингових компаніях;

2) економічні: простота та справедливість законодавчої системи, особливо при обліку та регламентації факторингу із міжнародною участю; ємність локального ринку та можливість застосування факторингових операцій; готовність банківських установ надавати факторингові послуги;

3) міжнародні: науково-технічне співробітництво між країнами 3 приводу реалізації факторингових послуг в рамках спільного підприємництва; міжнародне стажування персоналу - фахівців з факторингу.

Фактори макросередовища безпосередньо впливають на зовнішнє мікросередовище учасників факторингової операції, відповідно і на саме підприємство, що зацікавлене у реалізації факторингу. До факторів зовнішнього мікросередовища пропонуємо відносити наступні:

1) готовність ринку надавати споживати послугу - кількість підприємств, які готові або потенційно зацікавлені у використанні факторингових операцій;

2) рівень розвитку конкуренції та діяльність підприємств-конкурентів щодо здійснення ними таких операцій;

3) готовність фінансового ринку країни надавати послуги факторингу;

4) якісні та кількісні обмеження у отриманні короткострокових кредитних ресурсів.

Економічна ефективність факторингових операцій виявляється в тому, що факторинг дозволяє істотно підвищити ліквідність активів, рентабельність компаній та їхню платоспроможність i, як наслідок, сприяє економічному зростанню [9].

У світовій практиці під факторингом розуміється цілий ряд комісійнопосередницьких послуг, які проявляються у наступних аспектах:

1. В рамках цього виду послуг банк виплачує визначену суму від номіналу поставки (близько 60-90\%) у вигляді дострокового (авансового) платежу відразу після фактичного відвантаження товару, а залишок коштів (від 40 до $10 \%$ за вирахуванням комісій за факторингове обслуговування) банк переводить постачальнику в міру того, як покупець сплатить постачання на спеціальний факторинговий рахунок. Тобто банк в даному випадку є при особою, яка авансує товарний кредит, що надається постачальником покупцеві з майбутнім поверненням йому залишку суми поставки. 
2. Інформаційне забезпечення діяльності постачальника, ведення обліку стану його дебіторської заборгованості.

3. Страхування ризиків постачальника. Укладаючи договір факторингу, компанії отримують можливість виключити ризики, пов'язані з постачанням товарів на умовах відстрочки платежу: кредитний, ліквідний, валютний ризики.

4. Адміністративне управління дебіторською заборгованістю. Цей вид послуг включає контроль своєчасності оплати поставок, роботу з дебіторами, організацію для постачальника кредитного менеджменту, в тому числі встановлення лімітів на кожного з його покупців.

Щодо розвитку факторингу в Україні, то варто відзначити суттєве зниження обсягу факторингу у 2015 р., зниження фіксується на рівні майже 60 \% (таблиця), в той час як Румунія та Угорщина активно нарощують ринок факторингового обслуговування - приріст сягає майже 35 \%. На вітчизняному фінансовому ринку факторингового обслуговування провідну роль виконують банківські установи, а не факторингові компанії. У банках, які виконують роль факторів (ОТП Банк, Укрексімбанк, Райффайзен Банк Аваль, UniCredit Bank, банк «Хрещатик» - станом на початок 2015 р.) мінімальна річна ставка коливається від 20 \% до 30 \%. Комісія за встановлення факторингового ліміту складає від 0,5-1 \%. У таких банках, як Укрексімбанк та UniCredit Bank комісія відсутня. Комісія за обслуговування в ОТП Банк встановлена в розмірі від 0,1-0,9 \% (залежить от періоду відстрочки), в UniCredit Bank - 2-4 \%. В UniCredit Bank комісія за управління дебіторським боргом коливається від 1500 грн/міс., або 8 грн за кожну накладну. Максимальний період траншу (відстрочки платежу) коливається від 1 місяця (банк «Південний») до 4 місяців (ОТП Банк) [10, с. 105].

Таблиця

Стан розвитку факторингу в Україні та деяких країн-сусідів, 2015 р.

\begin{tabular}{|c|c|c|c|c|c|}
\hline \multirow[t]{2}{*}{ Показник } & \multicolumn{4}{|c|}{ Обсяг реалізованого факторингу, млн. євро } & \multirow{2}{*}{$\begin{array}{l}\text { Кількість компаній, } \\
\text { що надають послугу }\end{array}$} \\
\hline & Внутрішній & Зовнішній & Всього & $\begin{array}{c}\text { Відносна зміна, } \\
2015 / 2014, \%\end{array}$ & \\
\hline Білорусь & 130 & 190 & 320 & - & 5 \\
\hline Болгарія & 1456 & 364 & 1820 & +5 & 7 \\
\hline Румунія & 2903 & 748 & 3651 & +35 & 18 \\
\hline Польща & 27868 & 7152 & 35020 & +5 & 30 \\
\hline Словаччина & 621 & 415 & 1036 & 0 & 5 \\
\hline Угорщина & 3455 & 324 & 3779 & +34 & 18 \\
\hline Україна & 432 & 10 & 442 & -57 & 17 \\
\hline
\end{tabular}

Побудовано автором за даними FCI [6]

Негативною рисою розвитку факторингових послуг в Україні є велика частка пролонгування боргу, котрий сьогодні застосовують вітчизняні банки у 
тарифах за обслуговування. У розвинених країнах вартість факторингу становить у середньому близько 1,5-2 \% від суми постачання. В Україні середньозважена частка для ринку сьогодні, зазвичай, на 2-4 \% перевищує проточну банківську ставку, яку використовують під час короткотермінового крудитування клієнтів з аналогічним оборотом.

Однією із причин дисбалансу розвитку факторингу в Україні можна вважати непоінформованість підприємств як потенційних клієнтів про факторинг. Часто спостерігається ситуація елементарного незнання про дане поняття, про механізм його роботи, про його позитивні і негативні сторони.

Висновки. 3 огляду на проведене дослідження, варто зазначити, що постіндустріальні риси сучасного господарського комплексу породжують нові механізми взаємодії на фінансовому ринку. Відтак, поява та розвиток факторингових послуг провокує збільшення оборотності грошових коштів, оскільки у підприємства тимчасово вивільняються фінансові ресурси, які можуть бути використані ефективно за певний проміжок часу. Світові тенденції розвитку факторингу свідчать збільшення частки Південно-Східної Азії, але в той же час лідером на світовому ринку факторингу залишається Європа.

Наукова новизна полягає $\mathrm{y}$ : детермінації основних факторів макроекономічного характеру, котрі впливають на реалізацію факторингових операцій, що, на відміну від існуючих, конкретизовано та обгрунтовано такі 3 них - трудо ресурсні, економічні та міжнародні, що надасть змогу системно врахувати та своєчасно реагувати на зміну макроекономічного середовища; визначенні набору факторів зовнішнього мікросередовища учасників факторингової операції, що, на відміну від наявних, доповнені такими як готовність ринку надавати споживати послугу, рівень розвитку конкуренції та готовність фінансового ринку країни надавати послуги факторингу, зазначене надасть змогу поглибити теоретичні засади використання та активізації факторингового інструментарію серед потенційних учасників ринку.

Перспективами подальших наукових досліджень може бути розробка стратегічних напрямів розвитку організаційно-економічного забезпечення розвитку факторингу на вітчизняному ринку фінансових послуг.

\section{Література:}

1. Карп'як Я. С. Факторинг як інструмент вирішення фінансових проблем підприємства / Я.С. Карп'як, Л.І. Ріжко // Вісник Національного університету «Львівська Політехніка». Менеджмент та підприємництво в Україні: етапи становлення і проблеми розвитку - 2009. - H 647. - C. 70-72.

2. Поліщук О.В., Єгорова В.І. Удосконалення механізму регулювання факторингових послуг в Україні // Стратегія розвитку України (економіка, соціологія, право). - 2015. - № 2. - С. 80-88. [Електронний ресурс]. - Режим доступу: http://er.nau.edu.ua/bitstream/NAU/19076/1/\%D0\%9F\%D0\%BE\% D0\%BB\%D1\%96\%D1\%89\%D1\%83\%D0\%BA\%20\%D0\%9E.doc. 
3. Конвенція УНІДРУА «Про міжнародний факторинг» // [Електронний ресурс]. Режим доступу: http://zakon5.rada.gov.ua/laws/show/995_210

4. Ковтонюк О.В. Особливості реалізації міжнародного факторингу в контексті глобальної фінансової кризи [Електронний ресурс]. - Режим доступу: http://www.nbuv.gov.ua/old_jrn/Soc_Gum/KNP/172/knp172_165-168.pdf.

5. EU Forum for the Factoring and Commercial Finance Industry ... one mission, one platform, one voice. - Brussel: IFG secretariat, 2009. - $12 \mathrm{~s}$.

6. Міжнародна асоціація факторингу [Електронний ресурс] - Режим доступу. www.fci.nl

7. Казакова М. О. Факторингові послуги на ринку короткострокового кредитування України [Електронний ресурс]: Electronic Kyiv-Mohyla Academy Institutional Repository. Режим доступу: http://www.ekmair.ukma.edu.ua/bitstream/handle/123456789/3248/Kazakova_ Faktorynhovi_posluhy_na_rynku.pdf;jsessionid=853E1C8A5E1239EF3999C2533D495A39?sequ ence $=1$

8. Сисоєв О. В. Факторинг: функціональний аналіз [Електронний ресурс]: Національна бібліотека України ім. В. І. Вернадського. - Режим доступу: http://nbuv.gov.ua/jpdf/uazt_2013_5-6_25.pdf.

9. Гриценко В. В. Факторинг як ефективний інструмент підтримки бізнесу [Електронний pecypc]: Бібліотека наукових статей. - Режим доступу: http://www.stattionline.org.ua/ekonom/60/8067-faktoring-yak-efektivnij-instrument-pidtrimkibiznesu.html

10. Момот Л. В. Розвиток факторингу в Україні / Л. В. Момот // Наукові праці Національного університету харчових технологій. - 2015. - Т. 21, № 2. - С. 100-107. - Режим доступу: http://nbuv.gov.ua/UJRN/Npnukht_2015_21_2_15 